\title{
Factors controlling streambed coverage of Didymosphenia geminata in two regulated streams in the Colorado Front Range
}

\author{
Matthew P. Miller • Diane M. McKnight • \\ James D. Cullis · Alicia Greene · Kristin Vietti • \\ Daniel Liptzin
}

Received: 14 October 2008/Revised: 7 April 2009/Accepted: 17 April 2009/Published online: 6 May 2009

(C) The Author(s) 2009. This article is published with open access at Springerlink.com

\begin{abstract}
Didymosphenia geminata is a stalk-forming freshwater diatom which was historically found primarily in oligotrophic lakes and streams, but has recently become a nuisance species in many lotic systems worldwide. In the last 5-8 years, D. geminata has become established in Boulder Creek and South Boulder Creek, two regulated montane streams in the Front Range of the Colorado Rocky Mountains. Factors that may influence the growth of D. geminata
\end{abstract}

Handling editor: J. Saros

M. P. Miller · D. M. McKnight · J. D. Cullis Institute of Arctic and Alpine Research, Department of Civil, Environmental, and Architectural Engineering, University of Colorado, Boulder, Boulder, CO, USA

M. P. Miller $(\square)$

School of Forest Resources, The Pennsylvania State University, 312 Forest Resources Building, University Park, PA 16802, USA

e-mail:mpm18@psu.edu

A. Greene

Department of Biological and Agricultural Engineering,

Kansas State University, Manhattan, KS, USA

K. Vietti

Department of Ecology and Evolutionary Biology,

University of Colorado, Boulder, Boulder, CO, USA

\section{Liptzin}

Department of Environmental Science, Policy and Management, University of California, Berkeley, Berkeley, CA, USA were monitored during the summer of 2006. D. geminata abundance decreased in Boulder Creek after an unusual flood event caused by 3 days of sustained rainfall in the headwaters of the watershed. However, within a week, coverage had been restored to preflood levels. Variations in D. geminata abundance among sites were found to be negatively correlated with total dissolved phosphorus concentrations and bed movement, as measured by Shields stress. In contrast, D. geminata abundance was not significantly correlated with temperature, conductivity, $\mathrm{pH}$, total suspended solids, or dissolved inorganic nitrogen. Our results suggest that bed movement may be a dominant scouring mechanism that acts to control the growth and distribution of D. geminata. The potential role of total dissolved phosphorus and bed movement in decreasing D. geminata coverage adds to the limited base of knowledge regarding controls on the growth and distribution of this species, and could be investigated by researchers studying $D$. geminata blooms in other stream ecosystems.

Keywords Didymosphenia geminata .

Streams $\cdot$ Dams $\cdot$ Periphyton $\cdot$ Regulated flow

\section{Introduction}

Historically, the stalk-forming freshwater diatom, Didymosphenia geminata (Lyngbye) M. Schmidt, has been found primarily in alpine and boreal lakes and 
streams in Europe and North America (Krammer \& Lange-Bertalot, 1986). Recently, however, D. geminata abundance has increased dramatically and expanded to warmer waters of western states in the United States, Canada, India, Italy, and New Zealand, occupying diverse substrates and posing a threat to other aquatic organisms due to the formation of copious stalk material (Spaulding \& Elwell, 2007; Beltrami et al., 2008; Bhatt et al., 2008). In North America, nuisance blooms of the diatom were first reported over a decade ago (Sherbot \& Bothwell, 1993). More recently, conditions that promote D. geminata bloom events were investigated in Canadian rivers by Kirkwood et al. (2007). Perhaps the most dramatic example of the rapid spread of this diatom occurred on the South Island of New Zealand. The diatom was first found in October 2004 in the lower Waiau River (Kilroy, 2004). By April 2006, D. geminata had spread to 12 other rivers on the island (Spaulding \& Elwell, 2007). This rapid increase in D. geminata abundance has resulted in heightened awareness of the potential problems posed by the diatom.

Didymosphenia geminata mats differ from typical periphyton mats in streams because they do not easily slough off with senescence or a surge in flow (EPA, 2008). D. geminata cells produce stalks which terminate in adhesive pads. The long, branched stalks eventually form a thick, woolly mat that can be several centimeters thick. Larned et al. (2006) found that the biomass of $D$. geminata as ash-free dry mass was 250 times greater than the chlorophyll a content. This finding indicates that extracellular stalks, and not the cells themselves, are responsible for the high biomass of D. geminata mats. The thick mats of D. geminata can detach and clog water intakes, pipes, and filters. In Poland, the supply of water from the San River was impeded when filters were clogged with the "gelatinous material" formed from the diatom (Kawecka \& Sanecki, 2003).

Given the apparent rapid increase in the geographic range of D. geminata, greater knowledge of environmental factors controlling the growth of the species would be valuable. In the United Kingdom, it has been reported that D. geminata is favored in streams where organic phosphate is the major source of phosphorous (Elwood \& Whitton, 2007). In a study of two Canadian streams, it has been shown that water clarity, temperature, $\mathrm{pH}$, conductivity, and total phosphorus are important variables in determining the bloom development of D. geminata, and that D. geminata prefers regulated streams with low discharge and little variation in discharge (Kirkwood et al., 2007). Physical controls on the distribution of D. geminata in other stream ecosystems include water temperature and hydrologic stability (Kilroy et al., 2008; Kumar et al., 2009). In addition, it has been hypothesized that bed disturbance as a result of flood events, rather than simply an increase in flow velocity and associated shear stress, is a potential factor controlling the growth of D. geminata (Spaulding \& Elwell, 2007).

The main objective of this study was to evaluate the pattern of growth of D. geminata in summer in two regulated montane streams in the Colorado Front Range at sites near the outlets of their respective dams and several kilometers downstream. Several factors were examined that have been proposed to influence the growth of D. geminata, specifically hydrologic conditions, total suspended solids (TSS), and nutrient concentrations. Based on the results of other studies (e.g. Kirkwood et al., 2007; Kilroy et al., 2008), we hypothesized that hydrologic conditions would be the dominant driver in controlling the growth of $D$. geminata. Further, we hypothesized that bed movement is a scouring mechanism that can remove $D$. geminata mats attached to rocks and other substrates. The results presented here add to the existing knowledge base regarding controls on the growth of D. geminata.

\section{Materials and methods}

Site description

The streams examined in this study were Boulder Creek and South Boulder Creek in the Front Range of the Colorado Rocky Mountains (Fig. 1). Both streams are tributaries of the South Platte River. Boulder Creek runs from Barker Reservoir in Nederland, CO through the town of Boulder, CO, supplying $40 \%$ of Boulder's drinking water (BASIN, 2009). Highway 119, which connects Nederland and Boulder, runs alongside the creek and has high vehicular traffic. The Colorado Department of Transportation reports that on average approximately 5,000 vehicles per day travel this route (CDOT, 2009). A 
significant amount of sediment in the river likely comes from the heavy salting and sanding of the road.

South Boulder Creek runs through the town of Eldorado Springs, draining 30\% of the Boulder Creek watershed (BASIN, 2009). The creek is used for irrigation and water supply, as well as for recreational activity. Vehicular and human traffic have limited impacts on this creek because there is no road access for most of its length.

All three sites in Boulder Creek were adjacent to Highway 119 (Fig. 1). The first sampling site (BC1) was located approximately $2 \mathrm{~km}$ downstream of Barker
Reservoir (39 $58^{\prime} 24.78^{\prime \prime} \mathrm{N}$; $\left.105^{\circ} 27^{\prime} 52.86^{\prime \prime} \mathrm{W}\right)$. This site is sunny, shallow, and is a popular fishing area. The second sampling site (BC2) was approximately $5 \mathrm{~km}$ downstream of the dam $\left(39^{\circ} 58^{\prime} 57.12^{\prime \prime} \mathrm{N}\right.$; $105^{\circ} 26^{\prime} 45.54^{\prime \prime} \mathrm{W}$ ). The rocky stream bed receives full sun most of the day, and the gradient at this site is shallower than the other Boulder Creek sites. The flow at the two upstream sites (BC1 and $\mathrm{BC} 2$ ) is completely regulated by the outflows from Barker Reservoir which releases water from the top of the dam and impacts the magnitude and frequency of high flows, as well as potentially impacting water quality, temperature, and
Fig. 1 Map of Boulder County Colorado and insets showing the sampling locations for the study. Also, shown are the locations of the reservoirs and the two Colorado Division of Water Resources stream gages

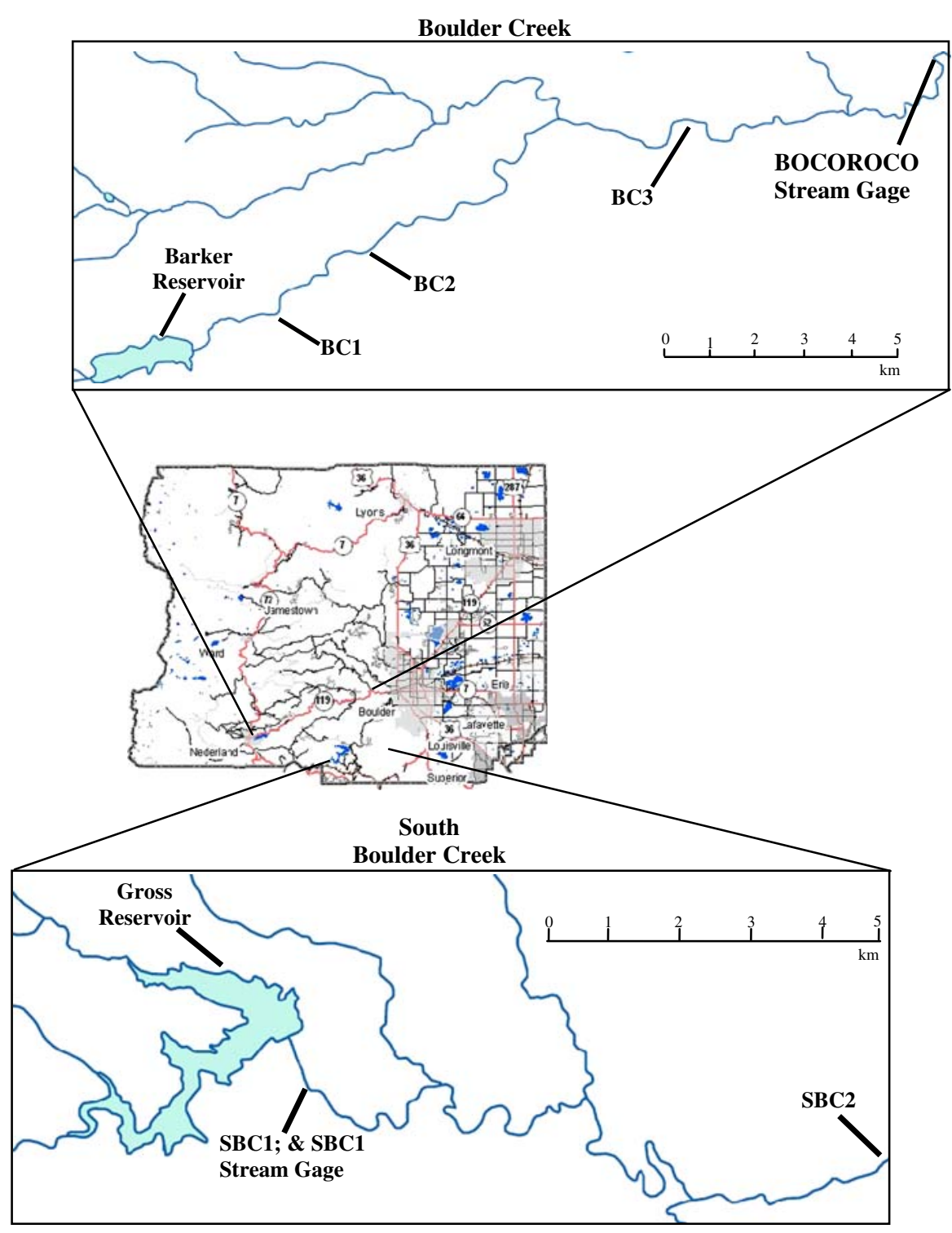


nutrient availability at the study sites. The final site (BC3) was located $15 \mathrm{~km}$ downstream of Barker Reservoir and a few kilometers downstream from Boulder Falls $\left(40^{\circ} 00^{\prime} 13.68^{\prime \prime} \mathrm{N} ; 105^{\circ} 22^{\prime} 50.22^{\prime \prime} \mathrm{W}\right)$, where North Boulder Creek flows into Boulder Creek. The stream is much deeper at this site and exhibits the highest flow rates of the five sampling sites. A few houses are located next to the stream, and the site is exposed to full sunlight. Site BC3 is downstream of the unregulated North Boulder Creek and as such the flows are only partially regulated.

The first sampling site in South Boulder Creek (SBC1) was located approximately $2 \mathrm{~km}$ from Gross Reservoir off of Flagstaff Road (39 $56^{\prime} 17.22^{\prime \prime} \mathrm{N}$; $105^{\circ} 20^{\prime} 49.08^{\prime \prime} \mathrm{W}$ ) (Fig. 1). Here, the flow and water quality are determined by the releases from Gross Reservoir, which releases water from the bottom of the dam. The site is isolated from most human activity, and is a half mile from the nearest road. The site receives full sun most of the day and experiences fast moving, turbulent flow. The second sampling site (SBC2) was located in the town of Eldorado Springs approximately $10 \mathrm{~km}$ below the dam $\left(39^{\circ} 55^{\prime} 56.82^{\prime \prime}\right.$ $\left.\mathrm{N} ; 105^{\circ} 16^{\prime} 47.16^{\prime \prime} \mathrm{W}\right)$. This site is near a gravel road which carries light vehicular traffic, is lightly shaded, and is adjacent to the backyards of several homeowners. The flow at both South Boulder Creek sites is completely regulated.

\section{Sampling and hydrologic monitoring}

Each of the five sites was sampled on a weekly basis from late June to early August during the summer of 2006. Temperature, conductivity, $\mathrm{pH}$, TSS, nutrients, and D. geminata coverage were measured at each site during each sampling event. Samples were also collected on three dates in March 2006 at site SBC2 and once at each site on September 20, 2006. Data collected on the March and September sampling dates are reported to provide preliminary data on D. geminata abundance in the spring and fall. However, the time frame of interest for this study is the summer months (June-August). Temperature, conductivity, and $\mathrm{pH}$ were measured in the field with a YSI 63 hand held meter.

For four of the five sampling sites, discharge data from nearby stream gages are available. The Colorado Division of Water Resources stream gage in Boulder Creek at Orodell (CDWR BOCOROCO gage) is located approximately $5 \mathrm{~km}$ downstream of BC3 (Fig. 1). Since there are no significant surface water inflows between site $\mathrm{BC} 3$ and the BOCORO$\mathrm{CO}$ stream gage, flow at $\mathrm{BC} 3$ was estimated as the flow measured at the BOCOROCO gage. Likewise, given the proximity of sites $\mathrm{BC} 1$ and $\mathrm{BC} 2$ to Barker Reservoir, and the absence of any significant surface water inflows to the creek in these reaches, flows were estimated as the flow release from Barker Reservoir which is monitored by the City of Boulder. Discharge at sites BC1 and BC2 was measured with a pygmy meter on July 4 and July 11, 2006. The South Boulder Creek stream gage located just downstream of the outlet of Gross Reservoir (CDWR BOCBGRCO gage) is at the same location as the SBC1 sampling site. Although there is a stream gage located approximately $2 \mathrm{~km}$ upstream of the SBC2 sampling site, data from this stream gage were not used to represent flow conditions at SBC2 because there is a significant diversion weir located between the gage and SBC2. Very little flow reaches SBC2 other than flood flows that overtop the weir.

Hydrologic analysis

In order to analyze the effect of flow conditions on D. geminata coverage, the hydrologic data were analyzed in terms of the average discharge for periods of 30- and 7-days leading up to any sampling event. The 30-day period corresponds to the time required for D. geminata to return to bloom levels as proposed by Kirkwood et al. (2007), while the 7-day time period corresponded with the average time interval between the sampling dates. Likewise, the average variance in flow for the discharge period of 30- and 7-days prior to any sampling event was calculated to represent the flow variability. These calculations were made for the four sites with available flow records (BC1, BC2, BC3, and SBC1).

At the Boulder Creek sites, a relationship was developed between the flow rate and the average shear stress and dimensionless Shields stress using a single channel cross section, the average bed slope, and the size distribution of the bed particles. The average bed slope and channel cross section were measured using an engineering level, while the particle size distribution was determined from 100 randomly selected stones across the entire stream bed in the vicinity of the measured cross section. This 
relationship was used to develop a time series of Shields stress data. The dimensionless Shields stress, which is the ratio of the average shear stress at the bed to the average particle size (Shields, 1936), was used as a measure of bed disturbance. Both 30- and 7-day average Shields stress values were calculated for the time period prior to a sampling event. The measurements required to make these calculations were not carried out at the South Boulder Creek sites due to sampling restrictions.

Water quality analyses

At each site, samples were collected for dissolved inorganic nitrogen (DIN) and total dissolved phosphorous (TDP) in 250-ml Nalgene HDPE bottles (Nalgene, Rochester, NY) and filtered through $1 \mu \mathrm{m}$, $47 \mathrm{~mm}$ Gelman A/E glass-fiber filters. DIN and TDP were analyzed at the Kiowa Laboratory following protocols of the Niwot Ridge Long-Term Ecological Research (NWTLTER) project (Kiowa, 2007). Samples for analysis of TSS content were collected from the streambed and $30.5 \mathrm{~cm}$ above, at one-fourth, onehalf, and three-fourths the distance across a stream transect and were analyzed following the methods of APHA (2000). TSS concentrations from all depths were averaged.

\section{Periphyton sampling}

Periphyton were sampled from mylar strips used as artificial substrate (McKnight \& Feder, 1984) and from rocks collected from the natural substrate at the site that were scraped clean prior to being deployed on July 20, July 27, and August 1, 2006 at all five sites. Strips of mylar film having dimensions $6.4 \times 29.2 \mathrm{~cm}$ were placed in riffles at each site on numerous dates. During high flow conditions at the start of the summer, many of the mylar strips were washed downstream and the aforementioned rocks were used as an alternative substrate at these sites. Nine days after the mylar strips and rocks were placed in the stream, a $5 \times 5 \mathrm{~cm}$ area was scraped from the remaining mylar strips and the rocks. The algal mat on each strip/rock was scraped into two 500-ml bottles and preserved with Lugol's solution. During the first weeks of the summer study, a rating scale (herein referred to as coverage) was developed as a qualitative measure of $D$. geminata cell coverage on the natural substrate across the streambed. The rating system was scaled from 0 to 10 , with 0 representing no visible streambed coverage of D. geminata at a given site and 10 representing $100 \%$ streambed coverage, with a mat thickness of approximately $2 \mathrm{~cm}$. For reference, a rating of 5 would correspond to moderately thick $(\sim 1 \mathrm{~cm})$ mats covering $50 \%$ of the streambed at a given site. This system allowed for classification of all the sampling sites by the abundance of $D$. geminata present each week.

Preserved samples were divided into 5 to $50 \mathrm{ml}$ aliquots and settled in Hydrobios gravity settling chambers. After a $30 \mathrm{~h}$ settling period, the samples were then observed under a Nikon inverted microscope. Each slide was viewed under $40 \times$ magnification and counted until at least 100 fields were counted. Cells per field were then converted to cells per square centimeter. In order to assess the influence of substrate type (mylar strips versus rocks) on algal colonization, cell densities were determined from both mylar strips and rocks at those sites where the mylar strips were not washed downstream.

\section{Statistical analyses}

Simple linear regression analyses were performed to investigate the relationships between the $D$. geminata coverage rating and environmental variables (temperature, conductivity, $\mathrm{pH}$, TSS, DIN, and TDP). These relationships were tested using the mean stream physical and chemical characteristics to predict the mean D. geminata coverage for the five sites from the summer months (June-August). This approach with sites as the replicates was chosen because the potential effects of stream chemistry on periphyton are assumed to be cumulative, and D. geminata coverage data were only collected on a weekly basis.

The simple linear regression approach was also used to examine the $D$. geminata coverage rating as a function of the D. geminata cell density, 30- and 7-day average flow (prior to the sampling date in question), 30- and 7-day variance in flow, and 30- and 7-day average Shields stress during the summer months. The relationship between cell density and D. geminata coverage was tested using measured cell densities on three dates at all the sites to predict D. geminata coverage. Similar to the chemical 
variables described above, hydrologic effects on D. geminata streambed coverage are also assumed to be cumulative. However, the hydrologic variables used in this study were collected on a daily time step from stream gages. This detailed information allows an examination using the conditions over the previous 7 and 30 day periods. The regression analyses were run separately for each of the four sites with reliable flow records $(\mathrm{BC} 1, \mathrm{BC} 2, \mathrm{BC} 3$, and $\mathrm{SBC} 1)$ with the six weekly samples of $D$. geminata as replicates.

\section{Results}

Hydrologic conditions

The seasonal pattern in discharge at the outlet to Barker Reservoir, the Boulder Creek gage, and the upstream South Boulder Creek gage during the summer of 2006 was typical of snowmelt-dominated systems (Fig. 2), with a peak in discharge during spring snowmelt in late May through early June. Following the snowmelt peak, the discharge decreased to baseflow conditions. At the outlet to Barker Reservoir, the snowmelt peak discharge was $6.9 \mathrm{~m}^{3} \mathrm{~s}^{-1}$ as compared with $10.9 \mathrm{~m}^{3} \mathrm{~s}^{-1}$ at the downstream gage in Boulder Creek. Flows measured at sites $\mathrm{BC} 1$ and $\mathrm{BC} 2$ on two dates in early July were nearly identical to the discharge at the outlet to Barker Reservoir on those dates (Fig. 2). The snowmelt peak discharge at SBC1 was $18.6 \mathrm{~m}^{3} \mathrm{~s}^{-1}$.

In the beginning of July, there was a continuous low intensity rain event that lasted for 3 days. Discharge at the outlet to Barker Reservoir during the rain event, $7.4 \mathrm{~m}^{3} \mathrm{~s}^{-1}$, was greater than the peak discharge during snowmelt (Fig. 2). Likewise, discharge at the downstream gage in Boulder Creek increased to $20.7 \mathrm{~m}^{3} \mathrm{~s}^{-1}$, nearly twice the snowmelt peak. In contrast, the rain event caused only a small peak in discharge at SBC1.

At the three Boulder Creek sites, changes in Shields stress followed a consistent temporal pattern (Fig. 2). There was an initial peak in Shields stress in early June during snowmelt. Shields stress values then gradually decreased until the rain event occurred, during which time the Shields stress values increased to the highest values calculated at all the three sites during the entire summer. Following the rain event, Shields stress values decreased throughout

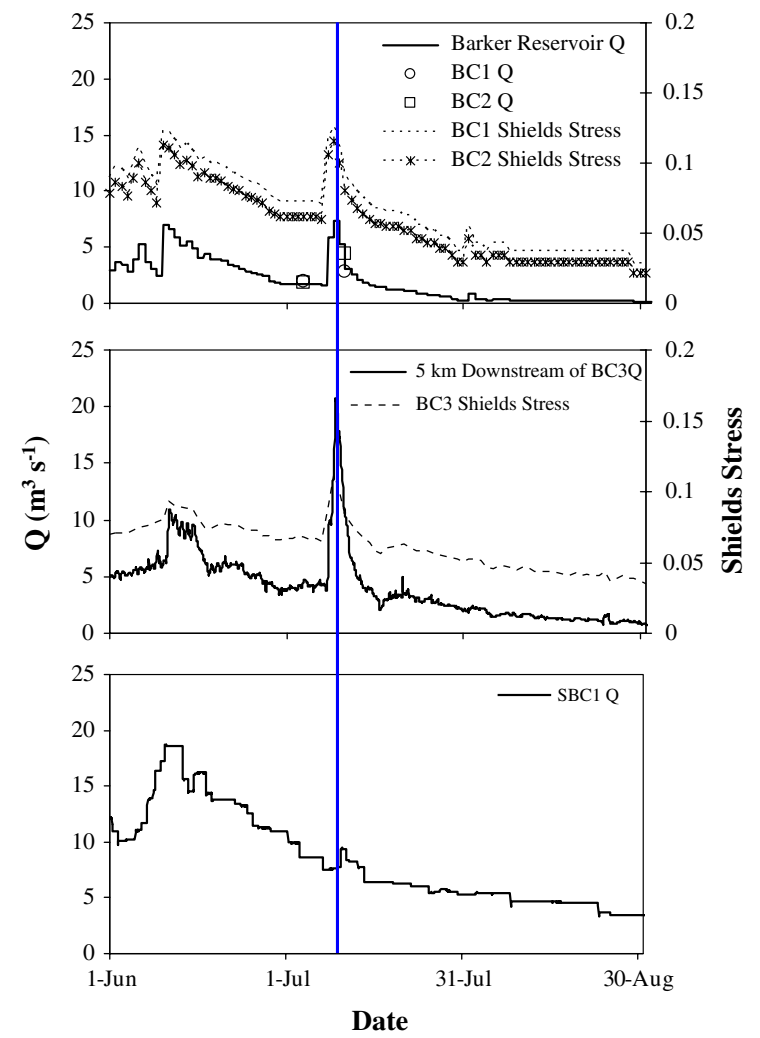

Fig. 2 Outflows from Barker Reservoir and discharge at the two Colorado Division of Water Resources stream gages used in this study. Discharge measurements at sites BC1 (open circle) and $\mathrm{BC} 2$ (open square) taken with a pygmy meter on two dates in July are also shown. " $Q$ " represents discharge. Also, shown are the Shields stress values at sites BC1, BC2, and $\mathrm{BC} 3$. The vertical line indicates the timing of the sustained rain event

the remainder of the summer. The dimensionless Shields stress values were relatively consistent between the sites. The average Shields stresses for sites $\mathrm{BC} 1, \mathrm{BC} 2$, and $\mathrm{BC} 3$ between June 1 and August 31 were $0.068,0.058$, and 0.055 , respectively. The maximum Shields stress values corresponding with the flood event on July 9 were $0.127,0.115$, and 0.112 , respectively.

Water quality

The concentrations of the total suspended solids at all five sites were low early in the summer (Fig. 3), and then TSS concentrations spiked following the July rain event. At the upstream sites $(\mathrm{BC} 1, \mathrm{BC} 2$, and SBC1), the TSS peak was lower than the TSS peak at the downstream sites (BC3 and $\mathrm{SBC} 2)$. In response to 

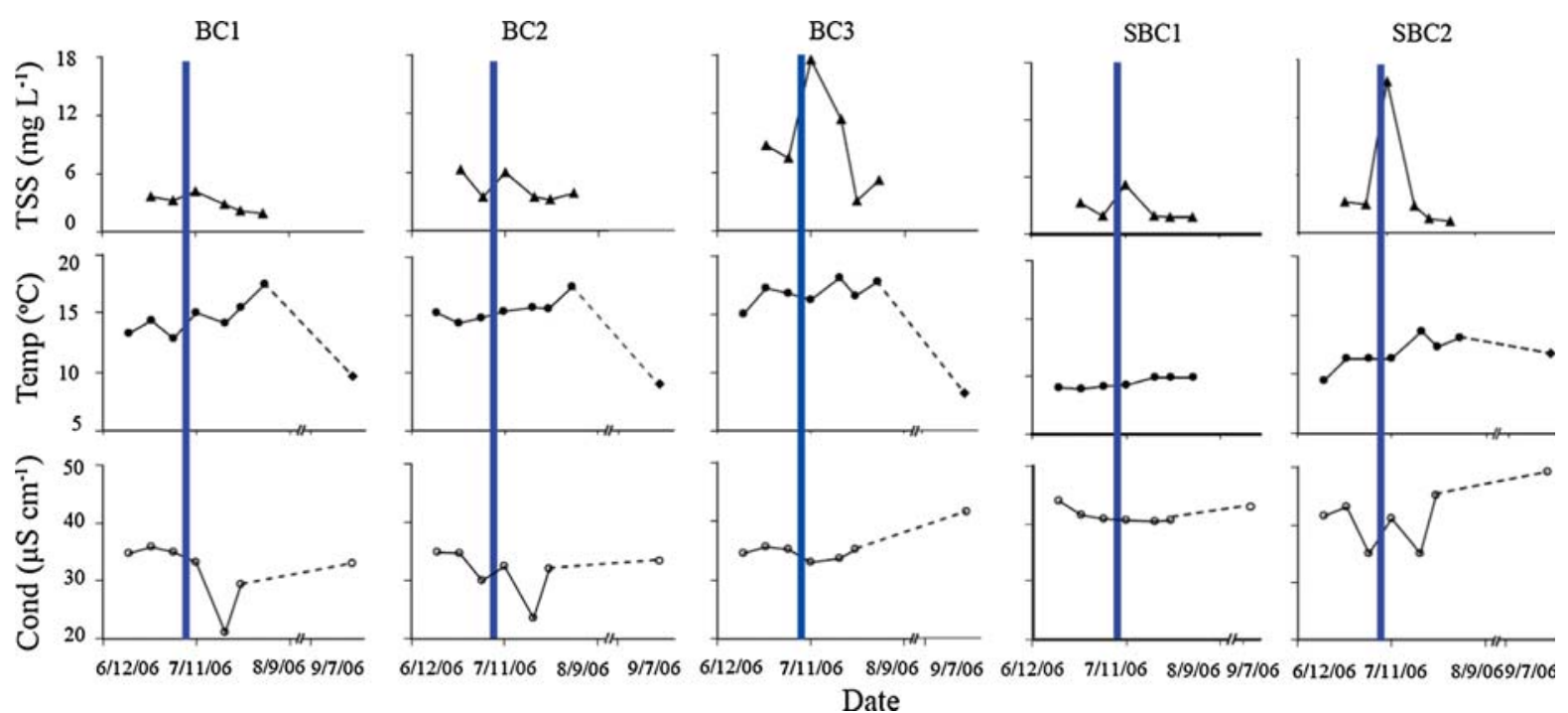

Fig. 3 Temporal variation in total suspended solids (TSS; solid triangles), temperature (Temp.; solid circles), and conductivity (Cond.; open circles) at the five sampling sites. The vertical lines indicate the timing of the sustained rain event

the rain event, TSS increased by a factor of 2 to $17.36 \mathrm{mg} \mathrm{l}^{-1}$ at site $\mathrm{BC} 3$ and by a factor of 5 to $15.7 \mathrm{mg}^{-1}$ at site SBC2.

At all three Boulder Creek sites temperature increased throughout the summer, and conductivity remained relatively constant (Fig. 3). Temperature at the Boulder Creek sites decreased during the fall. Two weeks after the rain event, there was a drop in conductivity at $\mathrm{BC} 1$ and $\mathrm{BC} 2$. Temperature at the South Boulder Creek sites was lower and conductivity was higher than at the Boulder Creek sites. At $\mathrm{SBC} 1$, both temperature and conductivity were relatively constant (Fig. 3). At site SBC2, temperature gradually increased throughout the summer and decreased during the fall. Conductivity remained relatively constant at SBC2 during the summer and increased during the fall. Two weeks after the rain event, there was a drop in conductivity at SBC2. On all the dates, the $\mathrm{pH}$ was circumneutral at all sites.

\section{Nutrient concentrations}

In general, $80 \%$ of the DIN concentrations at all sites was nitrate (average nitrate $=5.4 \mu \mathrm{Mol} 1^{-1}$ ) and the remaining $20 \%$ was ammonium (average ammo-

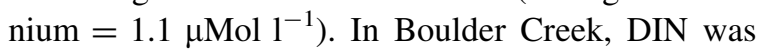
higher at $\mathrm{BC} 1$ and $\mathrm{BC} 2$ as compared with $\mathrm{BC} 3$ (Fig. 4). The July rain event had little effect on DIN below Barker Reservoir, at $\mathrm{BC} 1$, but resulted in a slight increase at $\mathrm{BC} 2$ and $\mathrm{BC} 3$. In late July, DIN increased by a factor of 2 at BC1. DIN was relatively constant at SBC1 and SBC2, varying between 3 and $8 \mu \mathrm{Mol}^{-1}$. DIN was slightly higher at SBC1 as compared with SBC2.

TDP concentrations were low $\left(0-0.25 \mu \mathrm{Mol}^{-1}\right)$ at all sites during the summer and peaked in the fall (Fig. 4). The fall peak in TDP was greater at the downstream sites as compared with the upstream sites in both creeks. There was little variation in TDP at $\mathrm{BC} 1$ throughout the summer. At $\mathrm{BC} 2$ and $\mathrm{BC} 3$, TDP peaked in September at 0.31 and $0.59 \mu \mathrm{Mol} \mathrm{l}^{-1}$, respectively. TDP was undetectable throughout the summer at SBC1. At SBC2, TDP increased consistently through the summer and into the fall, reaching a maximum concentration of $0.57 \mu \mathrm{Mol} 1^{-1}$.

\section{D. geminata coverage}

The thickness and coverage of D. geminata mats was highly variable between sites and over time. Once established, mat thickness generally ranged from 1 to $2 \mathrm{~cm}$. In Boulder Creek, there was a visible decrease in coverage following the rapid rise in discharge in July at all three sites (Fig. 5). Coverage was consistently higher at the $\mathrm{BC} 2$ site (7-10) during the summer as compared to sites $\mathrm{BC} 1$ and $\mathrm{BC} 3$. At sites $\mathrm{BC} 1$ and $\mathrm{BC} 2$, coverage decreased into the fall, whereas coverage increased in the fall at site $\mathrm{BC} 3$. 


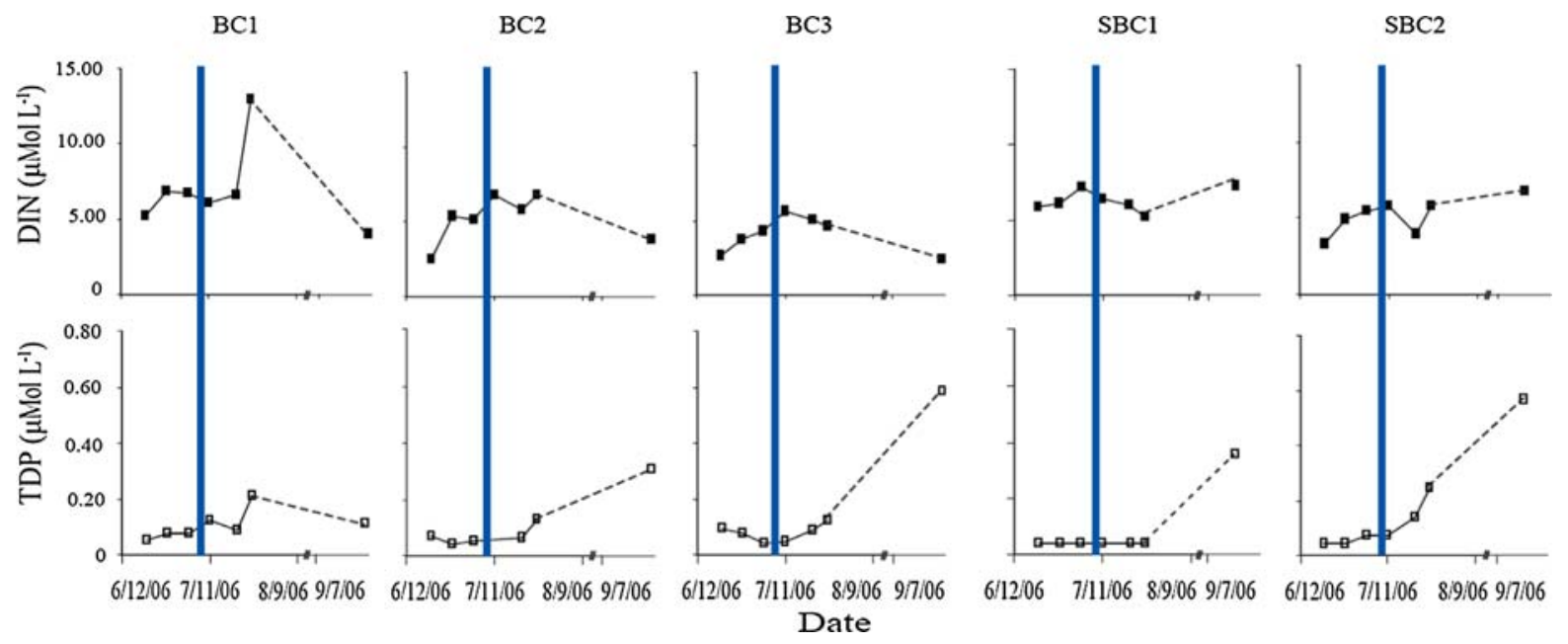

Fig. 4 Temporal variation in dissolved inorganic nitrogen concentrations (DIN; solid squares), and total dissolved phosphorous (TDP; open squares) at the five sampling sites. The vertical lines indicate the timing of the sustained rain event
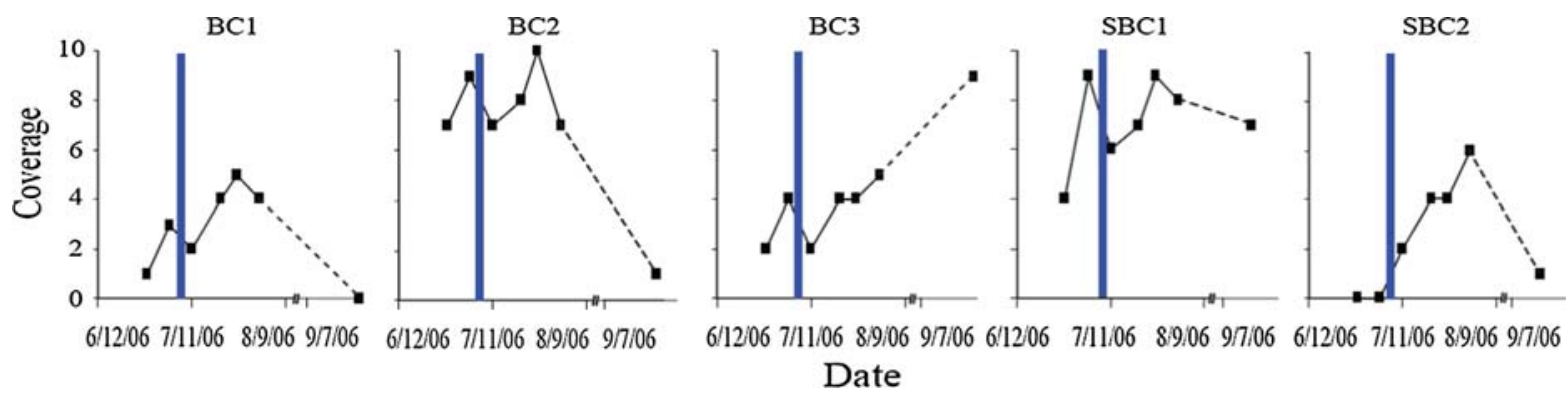

Fig. 5 Temporal variation in streambed coverage (as determined by the rating system) of $D$. geminata at the five sampling sites. The vertical lines indicate the timing of the sustained rain event

At SBC1, the coverage of D. geminata decreased following the rain event, whereas at the SBC2 site, D. geminata was not observed until after the rain event (Fig. 5). Coverage was consistently higher at SBC1 as compared with SBC2. While the coverage data are only shown for the summer months and for one fall sampling date, it is noteworthy that cell densities (which are related to coverage as shown below) of D. geminata at SBC2 in early March of $2006\left(6.5 \times 10^{3}\right.$ cells $\left.\mathrm{cm}^{-2}\right)$ were on the high end of those observed during the summer.

The density of $D$. geminata in the mats averaged $2.1 \times 10^{3}$ cells $\mathrm{cm}^{-2}$ and ranged from $2.7 \times 10^{2}$ cells $\mathrm{cm}^{-2}$ to $4.8 \times 10^{3}$ cells $\mathrm{cm}^{-2}$. Cell densities of the samples collected from mylar strips and rocks at a given site on a given date were within $10 \%$ of one another. There was a statistically significant positive relationship between cell density and coverage as measured by the rating method (Fig. $6, R^{2}=0.64$, $P<0.001, n=15)$. The microscopic analysis also showed that there were other small pennate diatoms associated with the D. geminata mats.

\section{Controls on the growth of $D$. geminata}

The results of the regression analyses among sites comparing the relationships between stream physical and chemical characteristics with the D. geminata coverage ratings are shown in Table 1. Average temperature, conductivity, $\mathrm{pH}$, TSS, and DIN values were not significantly associated with average D. geminata coverage. However, there was a statistically significant negative relationship between average TDP concentrations and average $D$. geminata coverage $(P=0.04)$. 


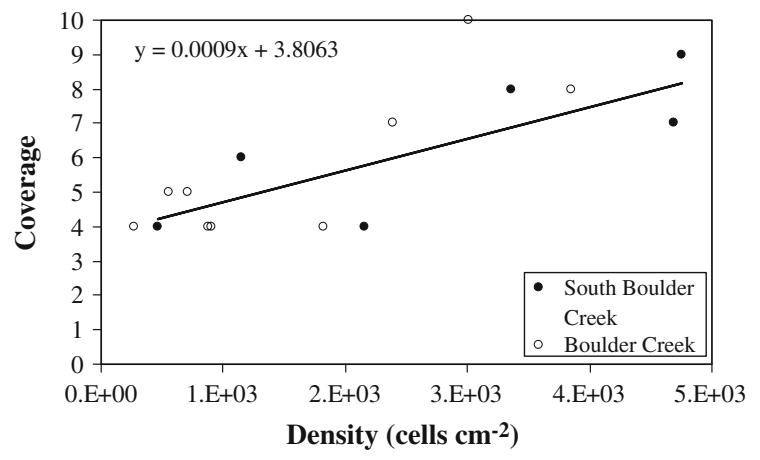

Fig. 6 Relationship between streambed coverage of D. geminata (rating method) and cell density for all sites. Cell density was significantly correlated with coverage $(P<0.001)$

Table 1 Relationships between stream physical and chemical parameters and $D$. geminata coverage ratings based on the site means

\begin{tabular}{llrlll}
\hline Variable & $n$ & Range & Slope & $R^{2}$ & $P$ \\
\hline Temperature $\left({ }^{\circ} \mathrm{C}\right)$ & 5 & $9.5-17.1$ & - & 0.06 & 0.69 \\
Conductivity $\left(\mu \mathrm{S} \mathrm{cm}{ }^{-1}\right)$ & 5 & $30.5-41.0$ & - & 0.02 & 0.83 \\
$\mathrm{pH}$ & 5 & $7.38-7.71$ & - & 0.26 & 0.39 \\
TSS $\left(\mathrm{mg} \mathrm{l}^{-1}\right)$ & 5 & $2.61-8.87$ & - & 0.12 & 0.57 \\
DIN $\left(\mu \mathrm{Mol} \mathrm{l}^{-1}\right)$ & 5 & $4.69-7.84$ & + & 0.003 & 0.92 \\
TDP $\left(\mu \mathrm{Mol} \mathrm{1} 1^{-1}\right)$ & 5 & $0.04-0.12$ & - & 0.82 & $\mathbf{0 . 0 4}$ \\
\hline
\end{tabular}

The nature of the association (positive or negative), $R^{2}$, and $P$ values for the simple linear regressions are shown for each predictor variable with significant relationships shown in bold. Also, shown are the range of values for the stream measurements

Within sites, there was a statistically significant negative relationship between discharge and D. geminata coverage at $\mathrm{BC} 1$ and $\mathrm{BC} 3$ at both the 30- and 7-day time scales (Table 2). In contrast, at sites SBC1 and $\mathrm{BC} 2$, there were no statistically significant relationships. At the 30-day time scale, there was a statistically significant negative relationship between the variance in discharge and D. geminata coverage at site $\mathrm{SBC} 1(P=0.03)$ (Table 2). At all the other sites, the relationships between the variance in discharge and D. geminata coverage were not significant. At sites $\mathrm{BC} 1$ and $\mathrm{BC} 3$ at both the 30- and 7-day time scales, there was a significant negative relationship between average Shields stress and D. geminata coverage. This relationship was not observed at the $\mathrm{BC} 2$ site.

\section{Discussion}

D. geminata abundance and rating system

This study of two streams in the Front Range of the Colorado Rocky Mountains investigated water quality and physical conditions below dams as potential factors controlling the growth and distribution of D. geminata. These two streams are representative of the conditions below dams in the western United States. Moreover, given the widespread distribution of D. geminata and the large number of regulated streams in the western U.S. (Spaulding \& Elwell, 2007), these results augment the limited information regarding controls on D. geminata growth. Furthermore, our results provide additional baseline information that may be useful in understanding the spread of D. geminata.

In assessing the role of hydrologic and water quality controls on D. geminata coverage in Boulder and South Boulder Creeks, the development of the D. geminata rating system has proven to be an efficient and useful tool that could be applied to other systems. For example, researchers could collect and count $D$. geminata cells in a small number of samples from their sampling sites and use the relationship reported in Fig. 6 to familiarize themselves with the rating system. The range of cell densities of $D$. geminata reported here $\left(2.7 \times 10^{2}\right.$ cells cm $\mathrm{cm}^{-2}$ $4.8 \times 10^{3}$ cells cm${ }^{-2}$ ) are of the same order of magnitude as values reported elsewhere (Kirkwood et al., 2007). The use of the rating system in concert with statistical analyses has provided insight into abiotic conditions that may control D. geminata abundance in regulated stream ecosystems.

\section{Hydrologic controls on D. geminata}

The results presented here (Table 2) and elsewhere (e.g. Kirkwood et al., 2007) suggest that D. geminata prefers sites with low mean discharge, low variation in discharge, and potentially shallow streambed gradients. It is possible that the high flows may act to scour D. geminata, which has an ash-free dry mass to chlorophyll $a$ ratio greater than 250 (Larned et al., 2006), indicating that the mats are mostly composed of stalk material. Biggs \& Close (1989), as well as Jowett \& Biggs (1997), reported that during scour of a periphyton mat caused by a flood, chlorophyll $a$ 
Table 2 Relationships between hydrological parameters and D. geminata coverage ratings by site using the six weekly samples during the summer

\begin{tabular}{|c|c|c|c|c|c|c|c|c|c|c|}
\hline Site & $n$ & Range & Slope & $R^{2}$ & $P$ & $n$ & Range & Slope & $R^{2}$ & $P$ \\
\hline \multicolumn{6}{|c|}{30 Day average $Q\left(\mathrm{~m}^{3} \mathrm{~s}^{-1}\right)$} & \multicolumn{5}{|c|}{7 Day average $Q\left(\mathrm{~m}^{3} \mathrm{~s}^{-1}\right)$} \\
\hline SBC1 & 6 & $3.40-13.3$ & + & 0.24 & 0.32 & 6 & $3.60-12.6$ & - & 0.37 & 0.20 \\
\hline BC1 & 6 & $1.76-3.96$ & - & 0.79 & 0.02 & 6 & $0.47-3.80$ & - & 0.68 & 0.04 \\
\hline $\mathrm{BC} 2$ & 6 & $1.76-3.96$ & - & 0.07 & 0.63 & 6 & $0.47-3.80$ & - & 0.18 & 0.40 \\
\hline BC3 & 6 & $4.55-6.22$ & - & 0.78 & 0.02 & 6 & $2.34-5.35$ & - & 0.75 & $\mathbf{0 . 0 3}$ \\
\hline \multicolumn{6}{|c|}{30 Day variance in $Q$} & \multicolumn{5}{|c|}{7 Day variance in $Q$} \\
\hline SBC1 & 6 & $1.79-18.5$ & - & 0.72 & $\mathbf{0 . 0 3}$ & 6 & $0.02-1.03$ & - & 0.19 & 0.39 \\
\hline BC1 & 6 & $1.59-2.84$ & + & 0.06 & 0.64 & 6 & $0.01-5.61$ & - & 0.16 & 0.43 \\
\hline $\mathrm{BC} 2$ & 6 & $1.59-2.84$ & - & 0.02 & 0.78 & 6 & $0.01-5.61$ & - & 0.16 & 0.44 \\
\hline $\mathrm{BC} 3$ & 6 & $2.40-12.5$ & + & 0.18 & 0.40 & 6 & $0.05-27.1$ & - & 0.37 & 0.20 \\
\hline \multicolumn{6}{|c|}{30 Day average Shields stress } & \multicolumn{5}{|c|}{7 Day average Shields stress } \\
\hline $\mathrm{BC} 1$ & 6 & $0.069-0.10$ & - & 0.72 & $\mathbf{0 . 0 3}$ & 6 & $0.046-0.095$ & - & 0.68 & 0.04 \\
\hline $\mathrm{BC} 2$ & 6 & $0.058-0.088$ & - & 0.04 & 0.71 & 6 & $0.037-0.084$ & - & 0.10 & 0.53 \\
\hline $\mathrm{BC} 3$ & 6 & $0.066-0.078$ & - & 0.71 & 0.04 & 6 & $0.054-0.083$ & - & 0.87 & 0.01 \\
\hline
\end{tabular}

The nature of the association (positive or negative), $R^{2}$, and $P$ values for the simple linear regressions with average flow, variances in flow, and average Shields stress at both the 30- and 7-day time scales are shown with significant relationships shown in bold. Also, shown are the ranges of values for the hydrological parameters. These analyses were only performed at the four sites near a stream gage

content associated with the mat was less likely to be scoured than was periphyton ash-free dry mass (e.g., non-chlorophyll $a$ stalk material). Kilroy et al. (2005) report that D. geminata biomass decreased following large flood events. The source of $D$. geminata to site SBC2 following the rain event (it was not present during the summer months prior to the rain event) may have been scouring at upstream locations during the rain event, and subsequent downstream transport of D. geminata cells. Furthermore, results suggest that stable flow conditions allow for D. geminata to outcompete other periphyton species (Kirkwood et al., 2007). This finding may in part explain the ability of $D$. geminata to rapidly colonize the substrate at the SBC2 site following the rain event. Likewise, the consistently high coverage (rating of 7-10; Fig. 5) during the summer months at the BC2 site may be due in part to the shallower gradient at this site as compared to the gradient at the other two Boulder Creek sites. The discharge at BC2 may not have been high enough to mobilize the bed and scour the D. geminata cells from the substrate. Further investigation into the importance of the relative amount of stalk to cell material in scouring of $D$. gemianta mats would be beneficial to understanding the mechanisms for controlling the removal of D. geminata from the substrate during high flow conditions.
Results presented here suggest that one potential mechanism for the scouring of D. geminata is bed movement, as measured by Shields stress. Shields stress is a measure of the potential for bed disturbance and this is considered to be one of the few factors that control the growth of $D$. geminata given its tolerance of a wide velocity range (Spaulding \& Elwell, 2007). Following the removal of D. geminata as a result of the flood event in July, Shields stress showed a much clearer distinction than average bed shear between this event and previous sampling periods that showed no removal of D. geminata. This finding supports the hypothesis that it is actual bed movement, rather than simply high levels of shear stress that are required to control the growth of D. geminata. It should be noted that our findings are from three sites in a single river and, while our results are promising, the importance of bed movement in controlling the growth and distribution of D. geminata in other systems should be investigated.

Water quality controls on D. geminata

It has been well documented that in headwater ecosystems, hydrologic conditions play an important role in controlling the water quality of aquatic environments (e.g. Lewis \& Grant, 1979; Boyer 
et al., 1997). Consequently, hydrologic and water quality conditions can interact to influence periphyton communities (e.g. Iwaniec et al., 2006).

Results from these two montane streams suggest that with the exception of TDP, the large changes in the hydrologic conditions of the stream ecosystems played a greater role in controlling D. geminata coverage than did the water quality conditions that were evaluated, as supported by the statistical analyses. The fact that there was little change in temperature, conductivity, or $\mathrm{pH}$ over time or between sites during the summer made it difficult to assess the importance of these variables as controls on D. geminata. In addition, the lack of a significant relationship between TSS or DIN and D. geminata may be misleading, given the small number of samples collected in this study. Further investigation into the importance of these variables as potential controls on the growth and distribution of D. geminata is warranted. In a study at a larger spatial and temporal scale, Kirkwood et al. (2007) showed that D. geminata prefers systems with lower turbidity, temperature, conductivity, and $\mathrm{pH}$. Nutrient enrichment experiments in New Zealand showed that $D$. geminata is limited by both nitrogen and phosphorus (Larned et al., 2006).

Studies in North American streams (Kirkwood et al., 2007; this study) show that unlike in New Zealand, D. geminata prefers systems with low total phosphorus (TP) and/or TDP concentrations. Elwood \& Whitton (2007) reported that D. geminata is favored in conditions where organic phosphate is the major phosphorus source. The negative relationships between TP and D. geminata observed by Kirkwood et al. (2007) and between TDP and D. geminata in this study suggest that competitive interactions between species with respect to phosphorus limitation may be a factor in Boulder Creek, South Boulder Creek, and the Canadian streams studied by Kirkwood et al. (2007). It is possible that in the Canadian streams and the Colorado streams that if phosphorus is limiting, the increase in TP and TDP gave other periphyton species a competitive advantage over D. geminata. Although this speculation warrants further investigation, the results presented by Kirkwood et al. (2007) and the results in this study show promise for TP and/or TDP as important parameters in determining the occurrence of D. geminata. Furthermore, the regression results provide preliminary data that may be useful, in concert with additional regression analyses conducted with samples from other systems, in developing predictive models for determining expected $D$. geminata coverage in regulated stream ecosystems.

\section{Conclusion}

The findings presented here provide additional information to the limited base of knowledge about water quality and hydrologic controls on D. geminata distribution and abundance in regulated stream ecosystems. Similar to the findings in other regulated streams in North America (e.g., Kirkwood et al., 2007), our results indicate that D. geminata prefers systems with low phosphorus concentrations and low mean discharge. In addition, our results indicate a promising role for bed movement as a potential mechanism of control on the growth of D. geminata in regulated streams. These results add to the knowledge base that may aid ecologists, engineers, and water resource managers in devising innovative methods for effectively controlling the growth and spread of this species. For example, our findings regarding the potential importance of TDP and increased bed movement as controls on D. geminata coverage may aid in the future development of predictive models that include water quality, hydrologic, and biologic parameters. The development of such models would allow for the testing of specific management plans designed to control the growth and distribution of D. geminata. This is of particular importance, given the potential impacts that $D$. geminata has on both natural and human systems and the increasing levels of concern regarding the spread of this species.

Acknowledgments This study was funded by the NSF's Niwot Ridge LTER Program (DEB-0423662) and Critical Zone Observatory project (EAR-0724960). Funding was also provided by the University of Colorado Environmental Engineering Research Experience for Undergraduates Program. S. Spaulding provided helpful comments on field study design and periphyton identification. M. Grant provided assistance with statistical analyses, and C. Wilson assisted with figure preparation. We are grateful for the field assistance provided by R. Laniello and S. Byrd. Helpful comments were also provided by two anonymous reviewers. 
Open Access This article is distributed under the terms of the Creative Commons Attribution Noncommercial License which permits any noncommercial use, distribution, and reproduction in any medium, provided the original author(s) and source are credited.

\section{References}

APHA, 2000. Standard Methods for Examination of Water and Wastewater, 21st ed. American Public Health Association, Washington, DC.

BASIN, 2009. Boulder Area Sustainability Information Network. http://bcn.boulder.co.us/basin/.

Beltrami, M. E., C. Cappelletti \& F. Ciutti, 2008. Didymosphenia geminata (Lyngbye) M. Schmidt (Bacillariophtya) in the Danube basin: new data from the Drava river (northern Italy). Plant Biosystems 142: 126-129.

Bhatt, J. P., A. Bhaskar \& M. K. Pandit, 2008. Biology, distribution and ecology of Didymosphenia geminata (Lyngbye) Schmidt and abundant diatom from the Indian Himalayan rivers. Aquatic Ecology 42: 347-353.

Biggs, B. J. F. \& M. Close, 1989. Periphyton biomass dynamics in gravel bed rivers: the relative effects of flows and nutrients. Freshwater Biology 22: 209-231.

Boyer, E. B., G. M. Hornberger, K. E. Bencala \& D. M. McKnight, 1997. Response characteristics of DOC flushing in an alpine catchment. Hydrological Processes 11: $1635-1647$.

CDOT, 2009. Colorado Department of Transportation. http:// www.dot.state.co.us/.

Elwood, N. \& B. Whitton, 2007. Importance of organic phosphate hydrolyzed in stalks of the lotic diatom Didymosphenia gemianta and the possible impact of atmospheric and climatic changes. Hydrobiologia 592: 121-133.

EPA, 2008. Environmental Protection Agency. Didymosphenia geminata: a nuisance freshwater alga. http://www.epa. gov/region8/water/didymosphenia/.

Iwaniec, D. M., D. L. Childers, D. Rondeau, C. J. Madden \& C. Saunders, 2006. Effects of hydrologic and water quality drivers on periphyton dynamics in the southern Everglades. Hydrobiologia 569: 223-235.

Jowett, I. G. \& B. J. F. Biggs, 1997. Flood and velocity effects on periphyton and silt accumulation in two New Zealand rivers. New Zealand Journal of Marine and Freshwater Research 31: 287-300.

Kawecka, B. \& J. Sanecki, 2003. Didymosphenia geminata in running waters of southern Poland-symptoms of change in water quality? Hydrobiologia 495: 193-201.

Kilroy, C., 2004. A New Alien Diatom, Didymosphenia geminata (Lyngbye) Schmidt: Its Biology, Distribution, Effects and Potential Risks for New Zealand Fresh Waters. National Institute of Water \& Atmospheric
Research Ltd, Christchurch, New Zealand, Client Report: CHC2004-128.

Kilroy, C., B. Biggs, N. Blair, P. Lambert, B. Jarvie, K. Dey, K. Robinson \& D. Smale, 2005. Ecological Studies on Didymosphenia geminata. National Institute of Water \& Atmospheric Research Ltd, Christchurch, New Zealand. Client Report: CHC2005-123.

Kilroy, C., T. H. Snelder, O. Floerl, C. C. Vieglais \& K. L. Dey, 2008. A rapid technique for assessing the suitability of areas for invasive species applied to New Zealand's rivers. Diversity and Distributions 14: 262-272.

Kiowa, 2007. Kiowa Environmental Chemistry Laboratory. http://snobear.colorado.edu/Seiboldc/kiowa.html.

Kirkwood, A. E., T. Shea, L. J. Jackson \& E. McCauley, 2007. Didymosphenia geminata in two Alberta headwater rivers: an emerging invasive species that challenges conventional views on algal bloom development. Canadian Journal of Fisheries and Aquatic Sciences 54: 1703-1709.

Krammer, K. \& H. Lange-Bertalot, 1986. Bacillariophyceae. Süsswasserflora von Mitteleuropa 2(1-4). VEB G. Fisher Verlag, Jena, Germany.

Kumar, S., S. A. Spaulding, T. J. Stohlgren, K. Hermann, T. Schmidt \& L. Bahls, 2009. Predicting habitat distribution for freshwater diatom Didymosphenia geminata in the continental US. Frontiers in Ecology and the Environment 7. doi:10.1890/080054.

Larned, S., B. Biggs, N. Blair, C. Burns, B. Jarvie, D. Jellyman, C. Kilroy, J. Leathwick, K. Lister, J. Nagels, M. Shacllenberg, S. Sutherland, J. Sykes, W. Thompson, K. Volpek \& B. Wilcock, 2006. Ecology of Didymosphenia geminata in New Zealand: Habitat and Ecosystem Effects-Phase 2. National Institute of Water \& Atmospheric Research Ltd, Chirstchurch, New Zealand. Client Report: CHC2006-086, NIWA Project MAF06507.

Lewis, W. M. \& M. C. Grant, 1979. Relationships between stream discharge and yield of dissolved substances from a Colorado mountain watershed. Soil Science 128: 353363.

McKnight, D. M. \& G. L. Feder, 1984. The ecological effect of acid conditions and precipitation of hydrous metal oxides in a Rocky Mountain stream. Hydrobiologia 119: 129-138.

Sherbot, D. M. J. \& M. L. Bothwell (1993). Didymosphenia geminata (Gomphonemaceae). A Review of the Ecology of D. geminata and the Physiochemical Characteristics of Endemic Catchments on Vancouver Island. National Hydrology Research Institute, Environment Canada, Saskatton, Sask. NHRI Contribution 93005.

Shields, A., 1936. Anwendung der Ahnlichkleitsmechanik und Turbulenzforshcung auf die Geschiebebewegung, Mitteil, Preuss. Versuchsanst. Wasser, Erd. Schiffsbau, Berlin, No. 26.

Spaulding, S. \& L. Elwell, 2007. Increase in Nuisance Blooms and Geographic Expansion of the Freshwater Diatom Didymosphenia geminata. Open-File Report 2007-1425. U.S. Geological Survey. 